Vol. 7 (1998): 423-436.

\title{
Concentrate feeding and milk yield based on field data of milk recorded herds
}

\author{
Kaisa Kaustell, Esa A. Mäntysaari and Pekka Huhtanen \\ Agricultural Research Centre of Finland, Animal Production Research, FIN-31600 Jokioinen, \\ Finland, e-mail: kaisa.kaustell@mtt.fi
}

\begin{abstract}
Field data from 16051 Finnish milk recorded herds including milk yield (MY), feed consumption, feed analyses, and the herd effect for milk yield (HMILK) obtained from the national breeding value estimation program, were analysed to detect the influence of concentrate feeding on milk production. HMILKs are deviations from the average national level with mean of $45 \mathrm{~kg}$ and SD of $722 \mathrm{~kg}$. Mean MY was $6917 \mathrm{~kg}$ and mean dry matter intake (DMI) $5679 \mathrm{~kg}$ per cow per year. The effect of concentrate feeding on HMILK and MY was studied by using quantitative [amount of energy (FUI) and concentrates (CI) in the diet] and qualitative [proportion of grain $(\mathrm{Gc})$ or compound feed $(\mathrm{Mc})$ in concentrates or $\mathrm{CP}$ content $(\mathrm{CPc})$ of concentrates] diet characteristics as dependent variables in multivariate regression analysis.

The general linear effect of CI was $1.18 \mathrm{~kg} \mathrm{MY} / \mathrm{kg}$ CI. Production response of CI decreased with increasing $\mathrm{CI}$ as indicated by significant interactions between $\mathrm{CI}$ and $\mathrm{CI}$ classes. Gc showed a negative relationship with HMILK, but CPc proved to be a more important factor affecting HMILK. Feeding grain instead of compound feed was connected with too low protein content in concentrates. Mc was positively correlated with CP content of concentrates. However, the use of compound feed appeared to give a slight increase in HMILK even after accounting for the effect of CP.
\end{abstract}

Key words: animal evaluation, compound feeds, dairy cows, grain, herd management, milk production

\section{Introduction}

Typically feeding intensity in dairy cattle is closely related to concentrate feeding. It could be hypothesised that an increase in amount of concentrates would lead into an increase in energy intake and therefore increased milk production. In short term feeding experiments increase in concentrate intake have resulted in smaller responses in milk yield than in longer complete lactation experiments (Wiktorsson 1979). It has been suggested that the effects of energy input are not fully realised short term. The carry over effect of, for example, low level of concentrate feeding, might not influence milk production during short term experiments but will affect subsequent lactation. To fully assess the impact 


\section{Kaustell, K. et al. Concentrate feeding and milk yield of herds}

of energy feeding, research has to be focused on whole lactation records, or to data measured across several lactations. Moreover, marginal responses to incremental concentrate feeding should be measured at different levels of input because productive responses usually respond according to the law of diminishing returns when nutrient supply varies around requirements.

In Finland $60 \%$ of dairy herds participate in milk recording and about $73 \%$ of total milk production comes from milk recorded herds. Most of these herds also estimate their feed consumption. The feed consumption database, which is linked with the milk recording and feed analysis databases, could provide a valuable view to practical on-farm feeding. The ration formulation program used on farms by advisory services is based on Finnish feeding recommendations (Tuori et al. 1995) and feed allowances are based on milk production. The program tends to divide home-grown forages evenly to cows within fill limits and satisfies energy and protein requirements with concentrates. Generally the amounts of forage offered to individual cows does not depend on milk yield and leads to large variations in the forage to concentrate ratio between cows within a herd.

Estimated breeding values of dairy cows are based on 305 day production. They are estimated using a statistical model (animal model) which in Finland includes the most important environmental effects such as herd-year, interaction between calving year and calving month, and calving age by days open effects within lactation number (Lidauer and Mäntysaari 1996). The largest variation in records is due to herd effects. In the evaluation model, the herd-year classification groups animals to subgroups of contemporaries that have produced under equal conditions. Thus, solutions of contemporary groups will express the effect of feeding and management of the herd. The herd-year effects (later on called herd effects) are estimated separately for first lactation and second and third lactations combined.

In the current investigation milk recording data was connected with solutions for herd ef- fect from the national breeding value prediction program. The same approach on a much smaller scale, was used by Agabriel et al. (1993). They found that the herd effects for milk composition, estimated by animal model on seventy-six French dairy farms, was related to feed characteristics such as type of concentrates and forage quality.

The objective of this paper is to describe the relationship between concentrate feeding and milk yield and animal model herd effects of milk yield based on data collected from Finnish dairy farms in 1993. The work is a part of a larger study that targets the development of farm management tools utilising information from monthly milk recording data.

\section{Material and methods}

\section{Data}

Data of milk production, feed consumption and feed analyses were obtained from milk recording databases. The total number of herds participating milk recording scheme in 1993 was 20 018, and after edits the total number of herds was reduced to 16051 with all essential data. Average number of cows per herd was 13.7 (SD 5.7). Three quarters of herds had between 8 and 19 cows and only $3 \%$ had more than 25 cows.

Milk yield is measured monthly according to the milk recording scheme. Samples for fat, protein and lactose analyses are taken bimonthly (Karjantarkkailutulokset 1993). Feed consumption is monitored on-farm by measuring feed stores in autumn and making feeding plans. Use of different feedstuffs for dairy cows is registered and reported three times per year; at the beginning, middle and at the end of the indoor feeding season.

Crude protein $(\mathrm{CP})$ content was determined using the Kjehldal method from 4014 grain and 2145 hay samples by Viljavuuspalvelu (Mikkeli, Finland). Feed analyses of silages were made by regional laboratories of Valio Ltd. (Helsinki, 
Vol. 7 (1998): 423-436.

Finland). A total of 35637 silage samples (from 11027 farms) had been analysed for dry matter (DM) content. Near infrared reflectance (NIR) spectroscopy was used for determining digestible organic matter in the DM (D-value ) (Hellämäki and Moisio 1991) and CP (Hellämäki and Moisio 1983) content of silage samples. Analysed composition was used in the calculation of feed values according to the Finnish feed evaluation system (Tuori et al. 1995). For those farms who had not sent feed samples for analyses feed table values were used.

Feeds were grouped into forages and concentrates. Forages included silage, hay, pasture and other roughages, mainly straw. Concentrates included grain, fibrous by-products (e.g. sugar beet pulp, wheat bran, barley fibre), compound feeds (commercial concentrate mixtures), protein supplements (rape seed meal, soya bean meal, compound feeds with $\mathrm{CP}$ content above $170 \mathrm{~g} / \mathrm{kg}$ ), minerals and other concentrates. Total feed consumption of dairy cows in a herd was divided by the number of cows to get the average intake per cow per year. Intake from pasture was estimated by subtracting the registered amount of feeds other than pasture from calculated total energy requirements based on milk production.

Herd effects for the year 1993 for cows in their 2. and 3. lactations were obtained from the national breeding value prediction program run in 1995. Evaluated traits were milk yield, protein and fat content and days open, somatic cell count and live weight. Only herd effects for milk yield (HMILK) are discussed here.

\section{Statistical analysis}

For preliminary examination of the data, correlations between milk production and feeding variables were calculated. Next a stepwise regression analysis was made using the selection based on the coefficient of determination $\left(\mathrm{R}^{2}\right)$. All feeding parameters were used in the stepwise regression analysis. Based on these results, the most important factors were included in analysis of variance and covariance. Factors consid- ered in latter models were total intakes (kg/cow/ year) of dry matter (DMI), crude protein (CPI), forages (FI), concentrates (CI), and energy (feed units/cow/year, FUI); content of $\mathrm{CP}$ in the total diet $(\mathrm{CPd})$, and in concentrates $(\mathrm{CPc}), \mathrm{g} / \mathrm{kg}$; proportion of concentrates in total diet $(\mathrm{Cd})$. Factors above were divided into 5-7 classes, depending on the effect, to allow and detect non-linear relationships.

When the quantitative effects of concentrate feeding were studied, average herd annual milk yield (MY) was used as dependent variable. CI was the most important factor to explain variation in MY $\left(R^{2}=0.36\right)$, as could be expected to result from feeding according to recommendations. Inclusion of other factors in the model after CI gave only a small increase in $\mathrm{R}^{2}$. The effect of the amount of concentrates offered to cows was studied by calculating the coefficients of regression of MY on CI within different concentrate intake groups. The model was:

$$
\text { [1.0] } \mathrm{MY}_{\mathrm{ij}}=\mu+\alpha_{1_{\mathrm{i}}}+\mathrm{b}_{1} \mathrm{CI}_{\mathrm{ij}}+\mathrm{b}_{1_{\mathrm{i}}} \mathrm{CI}_{\mathrm{ij}}+\varepsilon_{\mathrm{ij}} \text {, }
$$

where $\mu$ is intercept, $\alpha_{1_{\mathrm{i}}}$ is the effect of general level of CI $\left(\alpha_{1_{1}}:<1500, \alpha_{12}: 1500-1800\right.$, $\alpha_{1_{3}}: 1800-2100, \alpha_{1_{1}}: 2100-2400, \alpha_{15}:>2400 \mathrm{~kg} /$ year per cow), $b_{1}$ is the general regression of $\mathrm{CI}_{\mathrm{ij}}$ across CI classes and $b_{1_{i}}$ is the corresponding regression specific to $\mathrm{CI}$ class $\mathrm{i}$, where subscript refers to model [1.0]. Later $\mathrm{CPc}$ was included into [1.0] as a continuous variable (model [1.1]).

The criteria for finding the base model for HMILK was to get the highest possible $\mathrm{R}^{2}$ and the lowest possible residual SD with a reservation that factors in the model would not be strongly correlated with each other. Bearing these criteria in mind the following factors were selected to the base model: FUI, CPd and CI. Thus, the regression model was

$$
\text { [2.0] } \text { HMILK }_{\mathrm{ij}}=\mu+\mathrm{R}_{\mathrm{i}}+\alpha_{2_{\mathrm{i}}}+\mathrm{b}_{2_{\mathrm{i}}} \mathrm{FUI}_{\mathrm{ij}}+\mathrm{c}_{2_{\mathrm{i}}} \mathrm{CPd}_{\mathrm{ij}}+\varepsilon_{\mathrm{ij}} \text {, }
$$

where $\mu$ is intercept, $R_{i}$ is geographical region, $\alpha_{2_{\mathrm{i}}}$ is the effect of general level of CI $\left(\alpha_{21}:<1500, \alpha_{22}: 1500-1800, \alpha_{23}: 1800-2100\right.$, $\alpha_{24}: 2100-2400, \alpha_{25}:>2400, \mathrm{~kg} /$ year per cow $), b_{2 \mathrm{i}}$ 
Kaustell, K. et al. Concentrate feeding and milk yield of herds

and $\mathrm{c}_{2_{\mathrm{i}}}$ are linear regression coefficients for $\mathrm{FUI}_{\mathrm{ij}}$ and $\mathrm{CPd}_{\mathrm{ij}}$ on HMILK nested with levels of CI. This model resulted in $\mathrm{R}^{2}=0.45$ and $\mathrm{SD}=537$ $\mathrm{kg}$. It included two quantitative variables, FUI and CI, and a variable describing one aspect of diet quality, CPd.

Characteristics of concentrate feeding were studied by including the effects of proportion of grain $(\mathrm{Gc})$ and compound feed $(\mathrm{Mc})$ in concentrates $(\mathrm{g} / \mathrm{kg})$ to the base model [2]. Gc or Mc were added as linear regression effects nested within CI classes (models [2.1] and [2.3]) and CPc was similarly added after them (models [2.2] and [2.4]).

[2.1] HMILK $_{\mathrm{ij}}=\mu+\mathrm{R}_{\mathrm{i}}+\alpha_{2_{\mathrm{i}}}+\mathrm{b}_{2_{\mathrm{i}}} \mathrm{FUI}_{\mathrm{ij}}+\mathrm{c}_{2_{\mathrm{i}}} \mathrm{CPd}_{\mathrm{ij}}$ $+\mathrm{d}_{\mathrm{i}_{\mathrm{i}}} \mathrm{Gc}_{\mathrm{ij}}+\varepsilon_{\mathrm{ij}}$,

[2.2] HMILK $_{\mathrm{ij}}=\mu+\mathrm{R}_{\mathrm{i}}+\alpha_{2_{\mathrm{i}}}+\mathrm{b}_{2_{\mathrm{i}}} \mathrm{FUI}_{\mathrm{ij}}+\mathrm{c}_{2_{\mathrm{i}}} \mathrm{CPd}_{\mathrm{ij}}$ $+\mathrm{d}_{2_{\mathrm{i}}} \mathrm{Gc}_{\mathrm{ij}}+\mathrm{h}_{2_{\mathrm{i}}} \mathrm{CPc}_{\mathrm{ij}}+\varepsilon_{\mathrm{ij}}$

[2.3] HMILK $_{\mathrm{ij}}=\mu+\mathrm{R}_{\mathrm{i}}+\alpha_{2_{\mathrm{i}}}+\mathrm{b}_{2_{\mathrm{i}}} \mathrm{FUI}_{\mathrm{ij}}+\mathrm{c}_{2_{\mathrm{i}}} \mathrm{CPd}_{\mathrm{ij}}$ $+\mathrm{g}_{\mathrm{i}_{\mathrm{i}}} \mathrm{Mc}_{\mathrm{ij}}+\varepsilon_{\mathrm{ij}}$,

[2.4] HMILK $_{\mathrm{ij}}=\mu+\mathrm{R}_{\mathrm{i}}+\alpha_{2_{\mathrm{i}}}+\mathrm{b}_{2_{\mathrm{i}}} \mathrm{FUI}_{\mathrm{ij}}+\mathrm{c}_{2_{\mathrm{i}}} \mathrm{CPd}_{\mathrm{ij}}$ $+\mathrm{g}_{2_{\mathrm{i}}} \mathrm{Mc}_{\mathrm{ij}}+\mathrm{h}_{2_{\mathrm{i}}} \mathrm{CPc}_{\mathrm{ij}}+\varepsilon_{\mathrm{ij}}$,

where $d_{2_{i}}$ is linear regression for Gc, $g_{2_{i}}$ is linear regression for $\mathrm{Mc}$, and $\mathrm{h}_{2 \mathrm{i}}$ is a regression for $\mathrm{CPc}$ while the other effects are the same as in [2.0].

To study the nonlinearity of the effect of CPc the following nested models were used:

[3.0] HMILK $_{\mathrm{ij}}=\mu+\alpha_{3_{\mathrm{i}}}+\mathrm{b}_{3} \mathrm{CPc}_{\mathrm{ij}}+\mathrm{b}_{3_{\mathrm{i}}} \mathrm{CPc}_{\mathrm{ij}}+\varepsilon_{\mathrm{ij}}$, [3.1] HMILK $_{\mathrm{ij}}=\mu+\alpha_{3_{\mathrm{i}}}+\mathrm{b}_{3} \mathrm{CPc}_{\mathrm{ij}}+\mathrm{b}_{3_{\mathrm{i}}} \mathrm{CPc}_{\mathrm{ij}}+$ $\mathrm{c}_{3_{\mathrm{i}}} \mathrm{CI}_{\mathrm{ij}}+\varepsilon_{\mathrm{ij}}$

where $\alpha_{3_{\mathrm{i}}}$ is a effect of general level of CPc $\left(\alpha_{3_{1}}: 100-140, \alpha_{3_{2}}: 140-160, \alpha_{33}: 160-180\right.$, $\left.\alpha_{34}: 180-220 \mathrm{~g} / \mathrm{kg}\right), b_{3}$ is a general regression of $\mathrm{CPc}_{\mathrm{ij}}$ across CPc classes and $\mathrm{b}_{3_{\mathrm{i}}}$ is the corresponding regression specific to CPc class $i$ and $c_{3_{i}}$ is a general regression of $\mathrm{CI}_{\mathrm{ij}}$.

\section{Results}

Mean herd MY was $6719 \mathrm{~kg}$ (Table 1). In 95\% of the herds, MY was between $5231 \mathrm{~kg}$ and 8310 $\mathrm{kg}$. The HMILKs had a range of $6189 \mathrm{~kg}$. Mean DMI was $5679 \mathrm{~kg}$ per cow per year. The proportion of forage in DMI was $670 \mathrm{~g} / \mathrm{kg}$. Contents of $\mathrm{CP}$ in the whole diet and in concentrates were 150 and $156 \mathrm{~g} / \mathrm{kg} \mathrm{DM}$, respectively. Grass silage was the main forage as only a proportion of farms

Table 1. Description of the data.

\begin{tabular}{lrrrr}
\hline & Mean & SD & Minimum & Maximum \\
\hline $\begin{array}{l}\text { Production measures (/cow per year) } \\
\text { Milk yield, kg }\end{array}$ & 6719 & & & \\
Protein, g/kg & 32.8 & 936.6 & 2789 & 11853 \\
Fat, g/kg & 44.3 & 1.1 & 28.6 & 39.9 \\
HMILK, kg & 45.6 & 3.7 & 29.1 & 66.9 \\
Feed consumption (/cow per year) & & 722.2 & -2815 & 3374 \\
Dry matter intake, kg & 5679 & & & 9041 \\
FU intake & 5413 & 658.2 & 3367 & 9098 \\
CP intake, kg & 853 & 652.5 & 3050 & 1986 \\
Total diet CP, g/kg DM & 150 & 117.5 & 445 & 226 \\
Concentrate CP, g/kg DM & 156 & 10.3 & 83 & 324 \\
Forages, g/kg DM & 670 & 16.5 & 68 & 910 \\
Concentrates, g/kg DM & 330 & 67 & 250 & 750 \\
\hline
\end{tabular}

HMILK = animal model herd effect of milk yield, $\mathrm{kg}$; FU = feed unit (1 FU = 11.7 MJ ME, Tuori et al. 1995); $\mathrm{CP}=$ crude protein; $\mathrm{DM}=$ dry matter. 
Vol. 7 (1998): 423-436.

Table 2. Correlation coefficients between production and feeding variables in studied farms $(n=15722)^{1}$

\begin{tabular}{lrrrrrrrrrrr}
\hline & 1 & 2 & 3 & 4 & 5 & 6 & 7 & 8 & 9 & 10 & 11 \\
\hline 1. Milk yield, kg & & & & & & & & & & \\
2. HMILK, kg & 0.85 & & & & & & & & & \\
3. FU intake & 0.60 & 0.55 & & & & & & & & \\
4. Dry matter intake, kg & 0.55 & 0.49 & 0.97 & & & & & & & \\
5. CP intake, kg & 0.62 & 0.58 & 0.89 & 0.86 & & & & & & & \\
6. Concentrate intake, kg & 0.60 & 0.59 & 0.65 & 0.60 & 0.62 & & & & & & \\
7. Total forage intake, kg & 0.15 & 0.08 & 0.62 & 0.70 & 0.51 & -0.15 & & & & & \\
8. Concentrates, kg/kg DMI & 0.42 & 0.45 & 0.25 & 0.17 & 0.27 & 0.88 & -0.58 & & & & \\
9. Concentrate CP, g/kg DM & 0.24 & 0.27 & 0.14 & 0.12 & 0.34 & 0.25 & -0.08 & 0.24 & & & \\
10. Total diet CP, g/kg DM & 0.31 & 0.33 & 0.15 & 0.05 & 0.54 & 0.23 & -0.15 & 0.25 & 0.48 & & \\
11. Compound feeds, g/kg concentrates & 0.17 & 0.22 & 0.04 & 0.01 & 0.22 & 0.16 & -0.13 & 0.19 & 0.56 & 0.41 \\
12. Grain, g/kg concentrates & -0.14 & -0.17 & -0.04 & -0.03 & -0.23 & -0.19 & 0.13 & -0.21 & -0.68 & $-0.42-0.83$ \\
\hline
\end{tabular}

${ }^{1}$ Coefficients above 0.01 are statistically significant $\mathrm{P}<0.001$

HMILK = animal model herd effect of milk yield, $\mathrm{kg} ; \mathrm{FU}=$ feed unit (1 FU = 11.7 MJ ME, Tuori et al. 1995); $\mathrm{CP}=$ crude protein.

(10\%) used hay more than silage. Herds using silage were on average larger than those having hay as the main forage (14.0 vs 10.2 cows per herd). Most of the herds using silage fed hay in amounts recommended by feeding advisers, i.e. $2 \mathrm{~kg} /$ day/cow. There were 795 herds which did not use hay.

The parameters most positively correlated with MY and HMILK were CPI, CI and FUI (Table 2). On the other hand these were negatively correlated with the content of grain in concentrates.

The general linear effect of CI on MY was $1.18 \mathrm{~kg}(\mathrm{P}<0.001)$ (Table 3). When CPc was included in the model [1.0] the response decreased to $1.14 \mathrm{~kg} \mathrm{MY}(\mathrm{P}<0.001)$. The production response of CI decreased with increasing $\mathrm{CI}$ as indicated by a significant $(\mathrm{P}<0.001)$ interaction between linear effect of CI and CI group effects.

The means of feeding factors in different CI groups (Table 3 ) show that increasing the amount of concentrates, also increased the intake of compound feed and grain. The proportion of compound feed in the concentrates increased as CI increased whereas grain content slightly decreased. Silage CP content increased slightly, but silage D-value changed very little. Concentra- tion of urea in milk increased as inclusion level of $\mathrm{CI}$ increased but the mean values were all within limits $(20-30 \mathrm{mg} / 100 \mathrm{ml})$ recommended by feeding advisers in Finland. Supply of energy in relation to cow requirements ( $\mathrm{S} / \mathrm{R}$ ratio) increased with $\mathrm{CI}$, but the marginal response to increased supply of MJ of metabolizable energy (ME) did not change.

Coefficients of the base model for HMILK and the solutions for terms for composition of concentrates are shown in Table 4. The overall response to FUI was $0.34 \mathrm{~kg}$ HMILK per FU (model [2.0]). It was significantly different $(\mathrm{P}<0.001)$ in different $\mathrm{CI}$ classes, being higher in the lowest and highest classes than in the middle classes. Neither the linear response of FUI nor the interaction between FUI and CI classes changed when $\mathrm{CPc}, \mathrm{Gc}$ or Mc were added in the model. The overall response of CPd was on average $15.2 \mathrm{~kg}$ HMILK per g CPd (model [2.0]). It differed significantly $(\mathrm{P}<0.01)$ between $\mathrm{CI}$ classes with a positive trend along increasing CI classes. The interaction between CPd and CI classes lost its significance when Mc was added in the model although the linear effect of CPd remained significant.

When Gc was added in model [2.0] as a con- 
Kaustell, K. et al. Concentrate feeding and milk yield of herds

Table 3. Milk yield (MY) response to concentrate intake (CI) and characterisation of feeding factors in different concentrate intake groups.

\begin{tabular}{|c|c|c|c|c|c|c|c|}
\hline \multirow[b]{3}{*}{$\mathrm{N}$} & \multirow{3}{*}{$\begin{array}{r}\text { General } \\
\text { linear } \\
\text { effect }\end{array}$} & \multicolumn{5}{|c|}{ Concentrate intake, $\mathrm{kg} / \mathrm{cow}$ per year } & \multirow{3}{*}{$\begin{array}{l}\text { Significance } \\
\text { of interaction } \\
\text { with CI class } \\
\end{array}$} \\
\hline & & $<1500$ & $\begin{array}{l}1500- \\
1800\end{array}$ & $\begin{array}{l}1800- \\
2100\end{array}$ & $\begin{array}{l}2100- \\
2400\end{array}$ & $>2400$ & \\
\hline & & 3033 & 4082 & 4046 & 2572 & 2318 & \\
\hline \multicolumn{8}{|l|}{ kg MY/kg CI } \\
\hline Model $[1.0]^{1}$ & $1.18^{2 * * *}$ & $1.40^{3}$ & 1.28 & 1.04 & 0.91 & 0.96 & $* * *$ \\
\hline Model $[1.1]^{4}$ & $1.14 * * *$ & 1.39 & 1.26 & 0.99 & 0.85 & 0.88 & $* * *$ \\
\hline \multicolumn{8}{|l|}{ Group means: } \\
\hline Concentrate intake, kg & & 1290 & 1657 & 1943 & 2232 & 2725 & \\
\hline Compound feed intake, $\mathrm{kg}$ & & 364 & 487 & 626 & 822 & 1253 & \\
\hline Grain intake, $\mathrm{kg}$ & & 786 & 981 & 1085 & 1132 & 1121 & \\
\hline Total forage intake, $\mathrm{kg}$ & & 3874 & 3810 & 3777 & 3724 & 3626 & \\
\hline Total diet CP, g/kg DM & & 148 & 149 & 150 & 152 & 154 & \\
\hline Concentrate CP, g/ kg DM & & 151 & 154 & 156 & 159 & 164 & \\
\hline Grain, g /kg concentrates & & 683 & 678 & 655 & 623 & 571 & \\
\hline Compound, $\mathrm{g} / \mathrm{kg}$ concentrates & & 283 & 294 & 322 & 368 & 456 & \\
\hline Silage CP, g /kg DM & & 151 & 154 & 154 & 157 & 157 & \\
\hline Silage D-value, g /kg DM & & 688 & 691 & 690 & 689 & 693 & \\
\hline Silage intake, $\mathrm{kg}$ & & 1844 & 1915 & 1959 & 2008 & 2024 & \\
\hline Urea in milk, mg /100 ml & & 24.4 & 25.0 & 25.5 & 25.9 & 26.8 & \\
\hline $\mathrm{S} / \mathrm{R}$ ratio, $\%$ & & 107 & 109 & 111 & 113 & 117 & \\
\hline kg MY/MJ ME & & 0.11 & 0.11 & 0.11 & 0.11 & 0.11 & \\
\hline
\end{tabular}

${ }^{1}$ Model with CI intake group and linear regression of CI within CI intake groups.

${ }^{2}$ General regression across all CI groups.

${ }^{3}$ Within CI group regression.

${ }^{4}$ Model [1.1] plus regression effect on concentrate CP.

$\mathrm{CP}=$ crude protein; $\mathrm{S} / \mathrm{R}=$ supply of energy in relation to the requirements of the cow; $\mathrm{D}$-value $=$ content of digestible organic matter in DM;

tinuous variable (model [2.1]) it turned out to have a negative $(\mathrm{P}<0.05)$ relationship with HMILK. This suggests that increasing Gc decreases HMILK. The interaction between Gc and CI class was not significant. When the CPc was further added to model [2.1] (model [2.2]) the coefficient of linear regression of Gc became slightly positive but it was no more significant. Interactions between $\mathrm{Gc}$ and $\mathrm{CI}$ class or $\mathrm{CPc}$ and CI class were not significant.

Mc was positively correlated with CP content of concentrates, dietary $\mathrm{CP}$ content and with
CP intake (Table 2). The correlation between HMILK and Mc was also positive. When Mc was added into the base model (model [2.3]), the resultant linear regression coefficient of Mc was positive $(\mathrm{P}<0.001)$. When $\mathrm{CPc}$ was further added into the model the linear regression coefficient of Mc remained positive and significant $(\mathrm{P}<0.001)$ in contrast to the case with Gc. With $\mathrm{Mc}$ in the base model, the interaction between $\mathrm{CPd}$ and CI class was no more statistically significant (models [2.3] and [2.4]). Neither were the linear effect of $\mathrm{CPc}$ nor the interaction be- 
Vol. 7 (1998): 423-436.

Table 4. Regression coefficients from the base model for herd effect of milk by animal model (HMILK) and the solutions for refined models with the composition of concentrates.

\begin{tabular}{|c|c|c|c|c|c|c|c|}
\hline \multirow[b]{3}{*}{$\mathrm{N}$} & \multicolumn{7}{|c|}{ Concentrate intake, $\mathrm{kg} / \mathrm{cow}$ per year } \\
\hline & \multirow{2}{*}{$\begin{array}{c}\text { General } \\
\text { linear effect }{ }^{2} \\
15722\end{array}$} & $<1500$ & $\begin{array}{l}1500- \\
1800\end{array}$ & $\begin{array}{l}1800- \\
2100\end{array}$ & $\begin{array}{l}2100- \\
2400\end{array}$ & $>2400$ & \multirow[t]{2}{*}{$\begin{array}{r}\text { Significance } \\
\text { of } \\
\text { interaction } \\
\text { with CI class }\end{array}$} \\
\hline & & 3033 & 4082 & 4046 & 2572 & 2318 & \\
\hline \multicolumn{8}{|c|}{ Model $[2.0]^{1}\left(R^{2} 0.45, S D\right.$ 537) } \\
\hline $\mathrm{b}_{2_{\mathrm{i}}}(\mathrm{kg}$ HMILK/FUI $)$ & $0.34 * * *$ & $0.44^{3}$ & 0.29 & 0.29 & 0.29 & 0.39 & $* * *$ \\
\hline $\begin{array}{l}\mathrm{c}_{2_{\mathrm{i}}}(\mathrm{kg} \text { HMILK/g CPd }) \\
\text { Model }[2.1]^{4}\left(R^{2} 0.45, S\right.\end{array}$ & \multicolumn{7}{|c|}{ Model $[2.1]^{4}\left(R^{2} 0.45, S D 537\right)$} \\
\hline $\mathrm{b}_{2_{\mathrm{i}}}(\mathrm{kg}$ HMILK/FUI $)$ & $0.34 * * *$ & 0.44 & 0.29 & 0.29 & 0.29 & 0.38 & $* * *$ \\
\hline $\mathrm{c}_{2 \mathrm{i}}(\mathrm{kg}$ HMILK/g CPd) & $14.7 * * *$ & 12.6 & 11.7 & 14.4 & 15.4 & 15.8 & $* *$ \\
\hline $\mathrm{d}_{2 \mathrm{i}}(\mathrm{kg}$ HMILK/g Gc) & $-0.08 * *$ & 0.03 & 0.46 & -0.25 & 0.14 & 0.04 & ns \\
\hline \multicolumn{8}{|c|}{ Model $[2.2]^{4}\left(R^{2} 0.45, S D 536\right)$} \\
\hline $\mathrm{b}_{2 \mathrm{i}}(\mathrm{kg}$ HMILK/FUI $)$ & $0.34 * * *$ & 0.44 & 0.29 & 0.29 & 0.29 & 0.38 & $* * *$ \\
\hline $\mathrm{c}_{2_{\mathrm{i}}}(\mathrm{kg}$ HMILK/g CPd) & $13.8 * * *$ & 12.6 & 11.7 & 14.4 & 15.4 & 15.8 & $*$ \\
\hline $\mathrm{d}_{2 \mathrm{i}}(\mathrm{kg}$ HMILK/g Gc) & $0.04^{\mathrm{ns}}$ & 0.00 & 0.05 & -0.03 & 0.14 & 0.04 & ns \\
\hline $\mathrm{h}_{2}$ (kg HMILK/g CPc) & $2.37 * * *$ & 1.9 & 2.5 & 1.1 & 3.6 & 3.0 & $\mathrm{~ns}$ \\
\hline \multicolumn{8}{|c|}{ Model $[2.3]^{4}\left(R^{2} 0.45, S D 534\right)$} \\
\hline $\mathrm{b}_{2_{\mathrm{i}}}(\mathrm{kg}$ HMILK/FUI $)$ & $0.34 * * *$ & 0.44 & 0.30 & 0.30 & 0.29 & 0.38 & $* * *$ \\
\hline $\mathrm{c}_{2_{\mathrm{i}}}(\mathrm{kg}$ HMILK/g CPd $)$ & $13.3 * * *$ & 12.7 & 11.4 & 14.0 & 14.7 & 14.1 & ns \\
\hline $\mathrm{g}_{2_{\mathrm{i}}}(\mathrm{kg}$ HMILK/g Mc) & $0.18 * * *$ & 0.14 & 0.16 & 1.44 & 1.93 & 3.23 & $* * *$ \\
\hline \multicolumn{8}{|c|}{ Model $[2.4]^{4}\left(R^{2} 0.45, S D 534\right)$} \\
\hline $\mathrm{b}_{2_{\mathrm{i}}}(\mathrm{kg}$ HMILK/FUI $)$ & $0.34 * * *$ & 0.44 & 0.30 & 0.30 & 0.29 & 0.38 & $* * *$ \\
\hline $\mathrm{c}_{2} \mathrm{i}(\mathrm{kg} \mathrm{HMILK} / \mathrm{g} \mathrm{CPd})$ & $13.0 * * *$ & 12.3 & 11.0 & 13.9 & 14.1 & 14.0 & ns \\
\hline $\mathrm{g}_{2 \mathrm{j}}(\mathrm{kg}$ HMILK/g Mc $)$ & $0.17 * * *$ & 0.11 & 0.13 & 0.14 & 0.17 & 0.32 & $* * *$ \\
\hline $\mathrm{h}_{2_{\mathrm{i}}}(\mathrm{kg}$ HMILK/g CPc) & $0.64^{\mathrm{ns}}$ & 0.96 & 1.07 & 0.03 & 1.12 & 0.06 & $\mathrm{~ns}$ \\
\hline
\end{tabular}

${ }^{1}$ Base model: HMILK $_{\mathrm{ij}}=\mu+$ Region + CI group $+\mathrm{b}_{\mathrm{i}} \mathrm{FUI}_{\mathrm{ij}}+\mathrm{c}_{\mathrm{i}} \mathrm{CPd}_{\mathrm{ij}}$.

${ }^{2}$ General effect of FUI ignoring the interaction CIxFUI.

${ }^{3}$ Effect of FUI estimated within CI group.

${ }^{4}$ Follow the description for base model (footnotes 1,2,3).

$\mathrm{FUI}=$ Feed unit intake; $\mathrm{CP}_{\mathrm{d}}=$ diet $\mathrm{CP}$ content $\mathrm{Gc}=$ proportion of grain in concentrates; $\mathrm{Mc}=$ proportion of compound feed in concentrates

tween $\mathrm{CPc}$ and CI class significant in the model [2.4].

Responses to increases in CP content of concentrates on HMILK and the corresponding averages of feeding variables in different $\mathrm{CPc}$ groups are shown in Table 5. The linear effect of CPc was $11.7 \mathrm{~kg} \mathrm{HMILK} / \mathrm{g} \mathrm{CPc}(\mathrm{P}<0.001)$ and the response of $\mathrm{CPc}$ decreased with increasing $\mathrm{CPc}$ as indicated by a significant $(\mathrm{P}<0.001)$ interaction between the linear effect of $\mathrm{CPc}$ and $\mathrm{CPc}$ group effects. Data were restricted to include observations with $\mathrm{CPc}$ values only in the range of 100 to $220 \mathrm{~g} / \mathrm{kg}$. From low $\mathrm{CPc}$ to high $\mathrm{CPc}, \mathrm{CI}$ increased about $400 \mathrm{~kg}$ and a marked change in the composition of concentrates was observed. The content of compound feeds in concentrates increased from 63 to $578 \mathrm{~g} / \mathrm{kg}$ and grain content decreased from 844 to $413 \mathrm{~g} / \mathrm{kg}$. The $\mathrm{CP}$ content of silage decreased, but the D-value of silage changed only slightly with increasing level of CPc. Neither the S/R ratio nor the response of MY to increases in ME intake changed across $\mathrm{CPc}$ levels. Milk production per kg concentrate intake increased slightly. 
Kaustell, K. et al. Concentrate feeding and milk yield of herds

Table 5. Effect of concentrate crude protein content (CPc) on herd milk solutions (HMILK) and characterisation of feeding factors in different CPc groups.

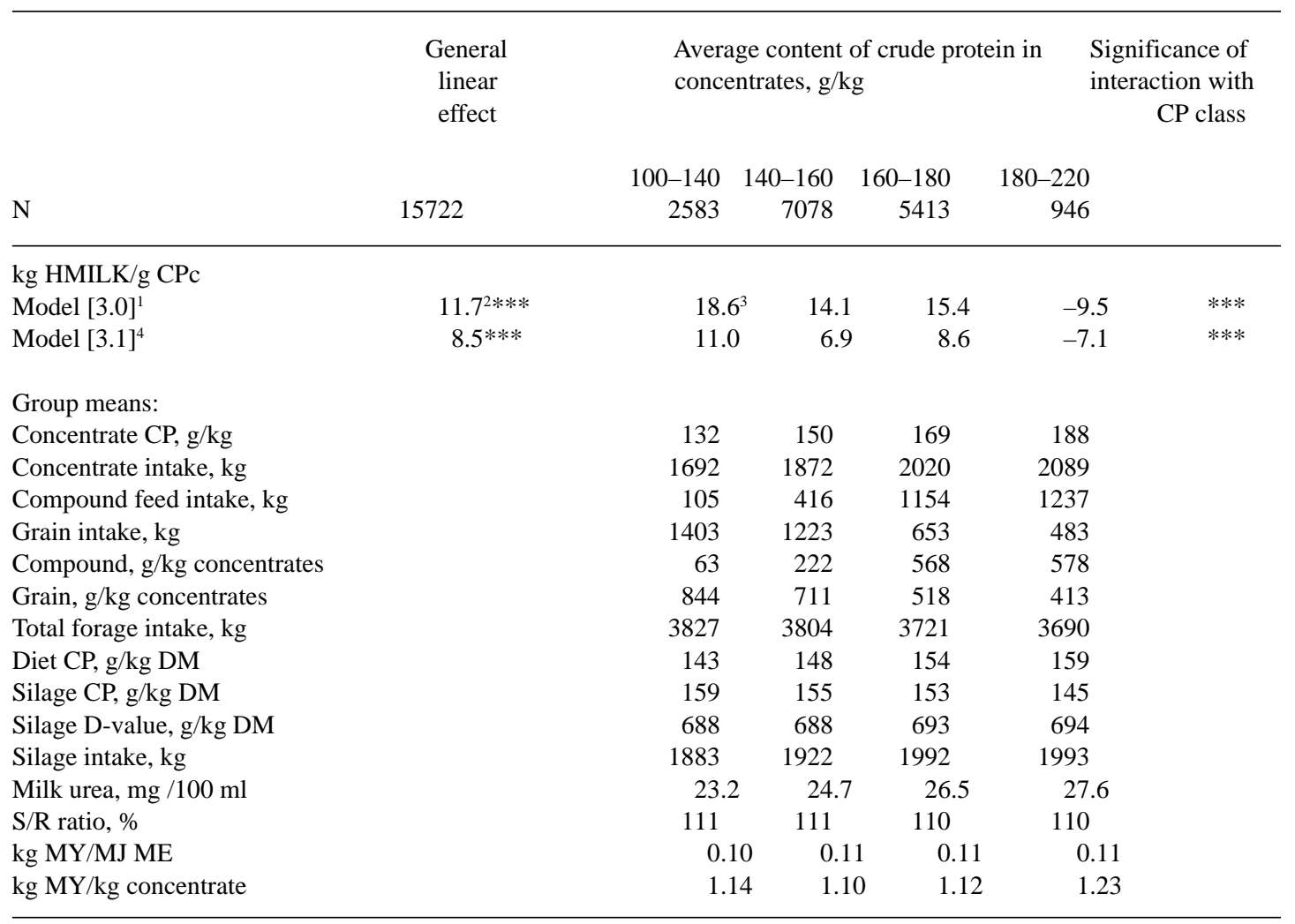

${ }^{1} \mathrm{HMILK}_{\mathrm{ij}}=\mu+\mathrm{CPc}$-group $+\mathrm{b} \mathrm{CPc}_{\mathrm{ij}}+\mathrm{b}_{\mathrm{i}} \mathrm{CPc}_{\mathrm{ij}}$

${ }^{2}$ Estimate for $b$.

${ }^{3}$ Within CPc-group estimates of $\mathrm{b}+\mathrm{b}_{\mathrm{ij}}$.

${ }^{4}$ Model [3.0] $+\mathrm{c}_{\mathrm{i}} \mathrm{CI}_{\mathrm{ij}}$.

$\mathrm{CP}=$ crude protein; $\mathrm{D}$-value $=$ content of digestible organic matter in DM; S/R =supply of energy in relation to cow requirements; $\mathrm{MY}=$ milk yield, $\mathrm{kg} / \mathrm{cow}$ per year

\section{Discussion}

In nutrition research analyses of field data are rare, thus we could not find any other studies of comparable size to the one presented here. Analysis of field data for nutritional means is difficult because of colinearity of factors, confounding effects due to feeding according to recommendations, and also because of the accuracy of estimation of feed intake is questionable. The present study focused on the effects of amount of concentrates on milk production because it was assumed that the intake of concentrates and their composition can be estimated more accurately than the intake of forages. Management of dairy herd includes various decisions from forage harvesting to choice of protein supplement. All these require expertise from the farmer. Many management practices appear to be associated with concentrate feeding. 
Vol. 7 (1998): 423-436.

\section{The effect of quantity of concentrates on milk production}

The HMILKs are deviations from national average level with a mean near zero (Table 1). A positive HMILK means that the herd is producing more milk than expected on the basis of cows' genetic potential, parity, calving season, calving age and days open. Thus, HMILK expresses the effects of herd feeding and management policies on milk production. As expected the correlation between HMILK and MY was high (Table 2).

Both HMILK and MY were closely associated with the total intake of concentrates (Table 2 ). This confirms the realisation of feeding recommendations: when cows produce higher yields the amount of concentrates fed will be increased. The majority of herds participating in the milk recording scheme follow feeding recommendations and feeding intensity is most often increased by increasing the amount of concentrates. Usually the amount of forages offered to individual cows does not depend on milk yield which leads into a substantial variation in the forage to concentrate ratio between cows within a herd.

As HMILKs are deviations that do not contain the herds' actual production level, they are not relevant for models using CI or other quantitative variables. For this reason MY was used as dependent variable in these analyses. The linear effect of one $\mathrm{kg}$ of concentrate DM was 1.18 $\mathrm{kg}$ MY when the general level of herds' concentrate intake varied from under 1500 to over 2400 $\mathrm{kg} /$ cow per year (Table 3). This was larger than the response of $0.79 \mathrm{~kg}$ milk per $\mathrm{kg}$ additional concentrate reported by Agnew et al. (1996) or 0.54 reported in a review of recent Finnish studies (Huhtanen 1998). Rinne et al. (1995) found a response of 0.51 when concentrate intake increased from 6.2 to $8.7 \mathrm{~kg}$ per day. All observed responses are much lower than the theoretical value of 2.38 (average energy content of $1 \mathrm{~kg}$ concentrates in this data divided by energy requirement for $1 \mathrm{~kg}$ milk).

Production responses of milk yield to addi- tional concentrate intake have been smaller in short term feeding experiments than in whole or multiple lactation experiments (Wiktorsson 1979). Residual effects have been variable depending on length of experiment, level of concentrate inclusion and forage feeding (Gordon 1984). At low levels of concentrate feeding, residual responses have been large and positive but at the highest inclusion level they have been negative. Effects might not be fully visible in milk production during an experiment, but they will affect the post-treatment period or subsequent lactation. The present data consists of annual milk production records of whole herds and thus is similar to whole or multiple lactation experiments.

Production responses calculated within CI classes diminished from 1.40 to 0.91 when the general level of concentrate intake increased from levels of $1500 \mathrm{~kg}$ or less to levels between 2100 and 2400 (Table 3). In the highest CI class (above $2400 \mathrm{~kg}$ concentrate per year) this coefficient was slightly higher indicating a curvi-linear response. However, one can question the accuracy of data in the lowest and highest CI groups which include borderline observations. There were outliers at both ends of the distribution although their number was minor compared to the size of the data set. Reduced response with increasing CI has also been shown in feeding experiments. In the literature review of Huhtanen (1998), changes in milk production due to additional concentrate intake $(\mathrm{kg} / \mathrm{kg} \mathrm{DM})$ were 0.94 , 0.80 and 0.64 when concentrate intakes were less than $5.0 \mathrm{~kg}$, between $5.0-7.3 \mathrm{~kg}$ or over $7.3 \mathrm{~kg}$ per day, respectively. Also in their multiple lactation experiment, Spiekers et al. (1991) found a decreasing production response to increases in concentrate intake.

The ratio of supply of energy to requirements ( $\mathrm{S} / \mathrm{R}$ ratio) increased along the intake of concentrates (Table 3 ). This could, firstly be due to overestimation of energy intake, secondly due to poor utilisation of increased intake of ME or thirdly due to a biased estimation of feed intake. The most apparent reason seems to be an overestimation of the increase in energy intake with increasing $\mathrm{CI}$, due to negative associative effects 
Kaustell, K. et al. Concentrate feeding and milk yield of herds

between forages and concentrates. These effects become important when the intake of high producing cows is limited by physical factors and therefore large amounts of concentrate supplements are needed to meet energy requirements (Huhtanen 1991). Increasing the level of concentrates in the diet results in a reduced rate of cell wall digestion, such that calculated increases in digestibility and metabolisability are not achieved.

Feeding level appears to have great influence upon negative associative effects (Mould 1988), such that these can be large at high levels of feeding. When considerable amounts of highly soluble carbohydrates from concentrates are included in the diet, digestibility of fibre is depressed. At a maintenance level of feeding, prolonged rumen retention time is able to compensate for the reduced rate of digestion, so that fibre digestibility will not decrease. In contrast, at high feeding levels, such as high producing dairy cows, digesta retention decreases more with high concentrate than high forage diets. Therefore a slower rate of digestion with high concentrate diets can not be compensated for by longer rumen retention time. Consequently, the depressive effect of feeding level on diet digestibility increases with the proportion of concentrate in the diet.

According to the Finnish feed tables (Tuori et al. 1995) diet digestibility is calculated to increase by $6 \mathrm{~g}$ per $\mathrm{kg}$ DM increase in the amount of concentrate whereas the observed change was $-1.8 \mathrm{~g}$ per $\mathrm{kg}$ concentrate DM in Finnish studies (Huhtanen 1998). This difference means that the increase in ME intake was $4 \mathrm{MJ}$ smaller than expected when the amount of concentrate was increased by $1 \mathrm{~kg} \mathrm{DM} / \mathrm{d}$. From calculated increases of energy intake only about $70 \%$ is typically realised. When forage prepared from high quality grass is fed, diet digestibility is not dependent on the proportion of concentrates, i.e. energy content of the diet does not increase by increasing the proportion of concentrates. In the experiment of Agnew et al. (1996) total ration digestibility was unaffected by concentrate inclusion level which varied between 2 and $8 \mathrm{~kg} /$ day. Also Rinne et al. (1995) found no change in the total ration digestibility of organic matter when concentrate allowance was increased from 7 to $10 \mathrm{~kg} /$ day.

The second reason for increased S/R ratio along with increased CI is poor utilisation of additional ME intake. This might not be very a obvious reason. In theory utilisation of $\mathrm{ME}$ should increase with $\mathrm{CI}$ because the proportion of ME in gross energy (GE) increases and efficiency of utilisation of ME in lactation $\left(k_{L}\right)$ should improve (ARC 1980). The third explanation covers the biased estimation of feed intake or forage energy value. This is not likely because the level of concentrate can not affect the intake of forage or feed values in a systematically biased way. Feed intake in the present data was actually the amount of feed given to cows, not the amount of eaten as refusals were not registered. The amount of refusal could have been larger at higher levels of concentrate allowance.

Larger responses to concentrate feeding in the present data compared to those obtained in feeding experiments are mainly due to feeding according to recommendations but there may also be other reasons such as restricted forage feeding. In feeding trials with restricted forage intake, production responses have been greater than in studies with ad libitum feeding (Johnson 1986). In the present study the higher response may partly be due to a limited intake of forage. Differences between responses to concentrates on restricted and ad libitum forage diets are due to substitution of concentrate for forage in the latter. The mean substitution rate (decrease in forage intake, $\mathrm{kg} \mathrm{DM} /$ increase in concentrate intake, $\mathrm{kg} \mathrm{DM}$ ) in the present data (Table 3) was much smaller than typical values of around 0.40.6 reported in feeding experiments and appears to be responsible for the high production responses. This is in agreement with the response of ME which was not changed with increasing concentrate intake (Table 3). The response of ME was surprisingly similar to the results of feeding experiments conducted in our institute (Rinne et al. 1995, Huhtanen 1998).

In feeding experiments with ad libitum for- 
Vol. 7 (1998): 423-436.

age feeding, increasing the amount of concentrates reduced the intake of forage with a substitution rate of around 0.50 (Spiekers et al. 1991, Aston et al. 1994b and 1995). Rinne et al. (1995) reported a substitution rate of $0.50-0.69$ on grass silage based diets cut at different stages of growth. In the experiment of Aston et al. (1994b), substitution rate was smaller with grass silages of high digestibility compared to silage of low digestibility.

In a whole indoor season experiment, Gordon (1984) reported a linear effect of level of concentrate supplementation on the intake of silage DM as described by the equation $y=1939$ $0.26 \mathrm{x}$, where $\mathrm{y}=$ intake of silage, $\mathrm{kg} \mathrm{DM}$ and $\mathrm{x}$ = intake of concentrates, kg DM. One possible factor behind a smaller substitution rate of total forage in the present data could be the restricted feeding of silage, which when conducted could cause average silage intakes to increase slightly with increasing CI (Table 3). This shows that feeding plans based on feeding recommendations have been followed in practice, as the ration formulation program used by advisers tends to restrict the allowance of forage for high yielding cows.

\section{Base model and composition of concentrates}

The effect of FUI on the HMILK was unexpectedly low in the present study. The theoretical value is as high as $2.27 \mathrm{~kg}$ milk per FU according to Finnish feeding recommendations (Tuori et al. 1995). In feeding experiments responses of around $1 \mathrm{~kg}$ are often achieved, for example in the experiment of Rinne et al. (1995) it was 1.3 $\mathrm{kg}$ milk per FU. The main reason for the small response in the present field data is that HMILK has been corrected for systematic environmental effects but the allowance of feeds is based on actual non-corrected production of milk. Thus quantitative feeding factors do not describe variation in HMILK particularly well. The FUI within CI class consists of both concentrates and forages and changes in forage intake affect the response.
The composition of concentrates changed when CI increased. Based on correlation coefficients, Gc decreased (Table 2) and Mc increased. Also the CP content of concentrates increased with increasing concentrate intake. A high proportion of grain was associated with a low content of CP in concentrates and in the total diet, and with a low CP intake.

The negative effect of Gc on HMILK (Table 4) was mediated by a low content of CP in the concentrate and the total diet, but the grain content as such did not have negative influence. This suggests that there is a shortage of protein in diets where concentrate feeding is based on cereal grains. One reason for insufficient use of protein supplements in practice could be the limits of milk urea content established by feeding advisory authorities. Avoiding high milk urea content might lead to minimal use of protein supplements, although in many cases the negative effect of a high urea content cannot be noticed. Shingfield et al. (1997) criticised, on the basis of evaluation of milk recording data, the current assessment of the upper milk urea limit in Finland (30 mg urea /100 ml milk) because performance of cows in herds with a high urea content was actually increased with little or no adverse effects on reproductive performance. Negative effects of high urea content are more obvious at levels much higher than current Finnish recommendations.

Commercial compound feeds differ from grain by their more complex composition and higher CP content which may explain the positive effect on HMILK. They are composed of a variety of materials besides grain such as byproducts of the food and alcohol industry and they include many kinds of protein and carbohydrate sources. However, although significant, the quantitative effect of proportion of compound feeds in concentrates was relatively small, i.e. HMILK increased $170 \mathrm{~kg} /$ year when Mc increased from 0 to $1000 \mathrm{~g} / \mathrm{kg}$. In experiments of Huhtanen $(1987,1991)$ and Huhtanen et al. (1988) feeding concentrates which were comprised of different types of carbohydrates were compared with feeding the corresponding ingre- 
Kaustell, K. et al. Concentrate feeding and milk yield of herds

dients alone. More complex mixtures of concentrates gave slightly higher milk yields. One effect of replacing starch in concentrates by digestible fibre seems to be an increased silage intake (Aston et al. 1994a).

The overall response of $\mathrm{CPc}$ was $11.7 \mathrm{~kg}$ $\mathrm{HMILK} / \mathrm{g} \mathrm{CP}$ in $\mathrm{kg}$ concentrate DM when the average $\mathrm{CP}$ content of concentrates increased from 100 to $220 \mathrm{~g} / \mathrm{kg} \mathrm{DM}$ (Table 5). When this annual response is converted to correspond to daily production, it appears little larger than responses reported by Aston et al. (1994a). In addition to different carbohydrate sources they also fed four different levels of concentrate $\mathrm{CP}$ from 120 to $240 \mathrm{~g} / \mathrm{kg}$, which resulted in a mean production response of $0.028 \mathrm{~kg}$ milk per additional $\mathrm{g} / \mathrm{kg} \mathrm{CP}$ in concentrates. They concluded that when cows were given silage ad libitum and 9 $\mathrm{kg}$ concentrates per day, milk production was more affected by CP content than source of carbohydrate. In the present data the importance of sufficient CP intake can also be seen.

Production response of $\mathrm{CPc}$ decreased when $\mathrm{CPc}$ level increased (Table 5). In the highest CPc level group the response was even negative. The response to $\mathrm{CPc}$ was lower when $\mathrm{CI}$ was included in the model, compared to that of CP content of concentrates alone. While cows with higher milk yield are fed with higher amounts of concentrates, CP content of concentrates also increased. The more a cow produces the more concentrates and concentrates richer in protein are used. Average silage CP content was lower when CPc was higher (Table 5). This indicates that the ration formulation scheme which in 1993 was based on digestible crude protein, is widely adopted on Finnish farms.

An increase in concentrate $\mathrm{CP}$ content has usually caused an increase in silage intake and milk yield (Aston et al. 1994a, Sutton et al. 1994). Replacement of $1.15 \mathrm{~kg}$ concentrate by rape seed meal induced a $0.69 \mathrm{~kg}$ increase in daily silage DM intake in the experiment of Rinne et al. (1995). In the present data the average intake of silage was increased by up to concentrate CP content of 160-180 g CP per kg DM.

\section{Conclusions}

The response to increased amount of concentrates in the diet was greater than generally observed in feeding experiments but much smaller than that derived theoretically. A larger response in field data is obviously related to the strict application of feeding recommendations indicated by a much smaller substitution rate than observed in feeding experiments. As a result of only small decreases in forage DMI with increased amounts of concentrates in the diet, the marginal responses to incremental ME were similar to values reported in feeding experiments.

The proportion of grain in concentrates showed a negative relationship to HMILK, but $\mathrm{CP}$ content of concentrates proved to be more important. Feeding grain instead of compound feed was typically associated with too low a protein content in concentrates. The proportion of compound feed was positively correlated with $\mathrm{CP}$ content of concentrates. However, the use of compound feed seemed to give slight increase in HMILK even after taking into account the effect of CP.

Acknowledgements. The authors are grateful to The Ministry of Agriculture and Forestry, Valio Ltd., Finnish Animal Breeding Association FABA, and Agricultural Data Processing Centre for participation and financing the research. Special thanks to Juha Nousiainen, Valio Ltd., for useful comments during the study and in preparing the manuscript. 
Vol. 7 (1998): 423-436.

\section{References}

Agabriel, C., Coulon, J.B., Marty,G. \& Bonaiti, B. 1993. Changes in fat and protein concentrations in farms with high milk production. Journal of Dairy Science 76: 734-741.

Agnew, K.W., Mayne, C.S. \& Doherty, J.G. 1996. An examination of the effect of method and level of concentrate feeding on milk production in dairy cows offered a grass silage-based diet. Animal Science 63: 21-21.

ARC 1980. The nutrient requirements of ruminant livestock. Agricultural Research Council. Commonwealth Agricultural Bureau. London. $351 \mathrm{p}$.

Aston, K., Sutton, J.D. \& Fisher, W.J. 1995. Milk production from grass silage diets: strategies for concentrate allocation. Animal Science 61: 465-480.

-, Thomas, C., Daley, S.R. \& Sutton, J.D. 1994a. Milk production from grass silage diets: effects of the composition of supplementary concentrates. Animal Production 59: 335-344.

-, Thomas, C., Daley, S.R. and Sutton, J.D. \& Dhanoa, M.S. 1994b. Milk production from grass silage diets: effects of silage characteristics and the amount of supplementary concentrates. Animal Production 59: 31-41.

Gordon, F.J. 1984. The effect of level of concentrate supplementation given with grass silage during the winter on the total lactation performance of autumn-calving dairy cows. Journal of Agricultural Science, Cambridge 102: 163-179.

Hellämäki, M. \& Moisio, T. 1983. Prediction of protein and fiber contents in silage by near infrared reflectance analysis. Milchwissenschaft 38: 14-15.

- Moisio, T. 1991. A system for silage evaluation. In: Pahlov, G. and Honig, H. (eds.). Proceedings of a conference on "Forage Conservation towards 2000". European Grassland Federation. 23-25 January 1991. Braunsweig.

Huhtanen, P. 1987. The effect of dietary inclusion of barley, unmolassed sugar beet pulp and molasses on milk production, digestibility and digesta passage in dairy cows given silage based diets. Journal Agricultural Science in Finland 59: 101-120.

- 1991. Associative effects of feeds in ruminants. In: Sundstøl. F. (ed.). Evaluation of the energy value of feeds for ruminants. Norwegian Journal of Agricultural Sciences Supplement no 5. p. 37-57.

- 1998. Supply of nutrients and productive responses in dairy cows given diets based on restrictively fermented silage. Agricultural and Food Science in Finland 7: 219-250.
-, Ala-Seppälä, H. \& Näsi, M. 1988. Response of silage intake and milk production to replacement of barley by barley fibre derived from integrated starchethanol process. Journal Agricultural Science in Finland 60: 711-721.

Johnson, C.L. 1986. Plane of nutrition. In: Broster, W.H. et al. (eds.). Principles and practice of feeding dairy cows. NIRD Technical bulletin 8. p. 25-43.

Karjantarkkailutulokset 1993. (Results of the milk recording in Finland 1993.) Maaseutukeskusten Liiton julkaisuja no 876, Helsinki, Finland. p. 41.

Lidauer, M. \& Mäntysaari, E.A. 1996. Detection of bias in animal model pedigree indices of heifers. Agricultural and Food Science in Finland 5: 387B396.

Mould, F.L. 1988. Associative effects of feeds. In: Ørskov, E.R. (ed.) World Animal Science B4, Feed Science. Elsevier, Amsterdam. p. 279-292.

Rinne, M., Jaakkola, S., Heikkilä, T., Huhtanen, P. \& Toivonen, V. 1995. Silage digestibility and concentrate supplementation in milk production. In: Nordiskt lantbruk i det nya Europa. Nordiska Jordbruksforskares Föreningens 20. kongress i Reykjavik 26-29 juni 1995. Rapport. Nordisk jordbruksforskning 77, 3: 124.

Shingfield, K.J., Huhtanen, P. \& Kaustell, K. 1997. Milk urea: It's use as diagnostic. In: Kotieläintieteen päivät 1997 Maaseutukeskusten Liiton julkaisuja no 914. Helsinki, Finland. p. 81-85.

Spiekers, H., Klünter, A.-M., Potthast, V. \& Pfeffer, E. 1991. Effects of different concentrate levels of milk yield, feed intake, live weight change, health and reproduction in dairy cows. Livestock Production Science 28: 89-105.

Sutton, J.D., Aston, K., Beever, D.E. \& Fisher, W.J. 1994. Milk production from grass silage diets: the relative importance of the amounts of energy and crude protein in the concentrates. Animal Production 59: 327334.

Tuori, M., Kaustell, K., Valaja, J., Aimonen, E., Saarisalo, E., \& Huhtanen, P. 1995. Rehutaulukot ja ruokinta-suositukset, märehtijät - siat - siipikarja - turkiseläimet-hevoset. (Finnish feed tables and feeding recommendations) Yliopistopaino. Helsinki 1995. $99 \mathrm{p}$.

Wiktorsson, H. 1979. General plane of nutrition for dairy cows. In: Broster, W.H. \& Swan, H. (eds.) Feeding strategy for the high yielding dairy cow. European Association of Animal Production, publication no 25. The Chaucer Press Ltd. UK. p. 148-170. 
Kaustell, K. et al. Concentrate feeding and milk yield of herds

\title{
SELOSTUS
}

\section{Väkirehuruokinnan vaikutus maidontuotantoon karjantarkkailutiloilta kerätyssä kenttäaineistossa}

\author{
Kaisa Kaustell, Esa A. Mäntysaari ja Pekka Huhtanen \\ Maatalouden tutkimuskeskus
}

Tutkimuksessa selvitettiin väkirehuruokinnan vaikutusta maidontuotantoon. Aineistona oli 16051 karjatarkkailutilan vuoden 1993 tuotos-, rehunkulutus- ja rehuanalyysitiedot sekä maitotuotoksen karjavuosiratkaisut. Karjavuosiratkaisut ovat tilakohtaisia jäännöspoikkeamia, jotka saadaan sivutuotteena ratkaistaessa jalostusarvot valtakunnallisella eläinmallilla. Karjavuosiratkaisut on korjattu karjassa tuottavien eläinten poikimakerran ja -iän, lypsykauden vaiheen sekä lehmien jalostusarvojen suhteen, ja siten ne kuvaavat ruokinnan ja hoidon vaikutusta maidon tuotantoon. Karjavuosiratkaisujen keskiarvo oli $45 \mathrm{~kg}$ ja keskihajonta $722 \mathrm{~kg}$. Korjaamaton keskituotos oli 6917 kg ja keskimääräinen rehujen kuiva-ainesyönti
5679 kg. Väkirehun määrän ja laadun vaikutusta karjavuosiratkaisuihin tutkittiin monimuuttujaregressioanalyysillä.

Väkirehun yleinen lineaarinen vaikutus keskituotokseen oli $1.18 \mathrm{~kg}$ maitoa/kg väkirehua. Tuotosvaste pieneni väkirehun annostuksen lisääntyessä. Tuotosvaste oli tässä tutkimuksessa suurempi kuin ruokintakokeissa, mutta selvästi pienempi kuin laskennallinen arvo. Väkirehun viljapitoisuus heikensi maitotuotoksen karjavuosiratkaisuja, mutta vaikutus johtui rehuannoksen liian matalasta raakavalkuaispitoisuudesta. Väkirehun täysrehupitoisuus paransi maitotuotoksen karjavuosiratkaisuja, vaikka väkirehun raakavalkuaispitoisuus otettiinkin huomioon. 